\title{
Instead of a Novel
}

\section{Sophia Yablonska's Travelogues in the History of Modern Ukrainian Literature}

\author{
Olena Haleta
}

\begin{abstract}
This article focuses on the life and literary strategies of Sophia Yablonska (1907-1971), a self-identified Ukrainian camerawoman, photographer, and writer. While working for a French documentary production company, traveling around the world, and living in Morocco and China, Yablonska published three books of travelogues supported by hundreds of photos (The Charm of Morocco, 1932; From the Country of Rice and Opium, 1936; and Distant Horizons, 1939) that combine autobiographical and anthropological approaches and transgress poetic and narrative conventions. In her travelogues, Yablonska examines the contradictions between traditional and modern culture and expresses them in verbal and visual forms. Abandoning the genre of the novel for that of the travelogue, Sophia Yablonska transgressed literary and life norms in terms of genre, gender, anthropology, autobiography, perception, media, culture, and discourse. Her writings not only reveal other countries, but also show the formation of a modern personality in the process of writing.
\end{abstract}

KEYWORDS: anthropological writing, autobiography, travelogue, transgression, Ukrainian literature, women's prose, Sophia Yablonska

"It's strange how one can easily become an original and interesting person. Very often, it's enough to be a stranger among this group of 'ours'!" -Sophia Yablonska

Sophia Yablonska, a self-identified Ukrainian and a Ukrainian-speaking camerawoman, photographer, and writer of the interwar period, is almost unknown in Ukrainian literature, despite the fact that her works have attracted readers among her contemporaries and those of the present day. Her atypical writings have never been included in the history of Ukrainian literature or literary anthologies, although each new 
(re)publication of her work has struck a deep chord with a new audience. Moreover, critics have usually overlooked the fact that her publications are a coherent narrative consisting of both her text and her photographs.

Yablonska was born in 1907 in the small village of Hermaniv, near Lviv (in Galicia, the western region of Ukraine) in the Austro-Hungarian Empire; she grew up in the Second Polish Republic (also spent several childhood years in the Russian Empire) and received her professional education in France. ${ }^{1}$ It was a turbulent period of "the birth of a nation" in Ukrainian history, when the independence and integrity of Ukraine as a state was proclaimed and soon lost after World War I: "Czechs and Slovaks, Poles and Lithuanians — the Western neighbors of Ukraine-all got independent state [while] Ukraine found itself divided not between two countries, as before World War I, but amoung four." ${ }^{2}$ These political changes, in particular, prompted many to migrate west in search of better conditions.

Forced to leave her home as a child during World War I, Sophia Yablonska decided to build her life in such a way that she would never become an exile. Her principal dream was to travel the world, and traveling became a way to remain independent. While working for a French documentary production company, traveling, and living in Morocco and China, Yablonska published three travelogues accompanied by hundreds of photos (The Charm of Morocco, 1932; From the Country of Rice and Opium, 1936; and Distant Horizons, 1939) that combine autobiographical and anthropological writ-

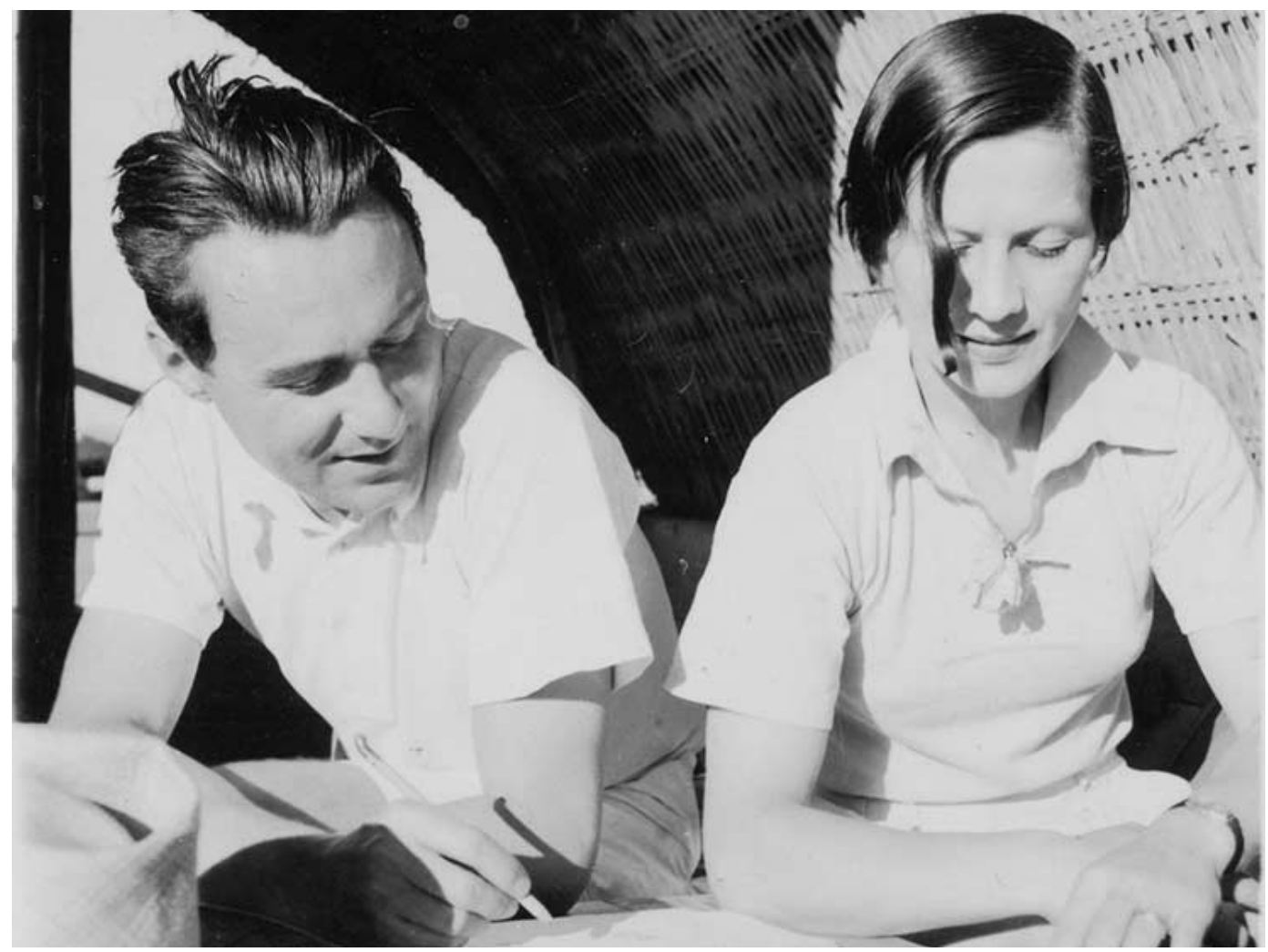

Figure 1: Sophia Yablonska with her husband, Jean Oudin. ${ }^{4}$ 
ing and transgress the poetical and narrative frameworks of Ukrainian literature of that time. After Yablonska's death in France in 1971, her colleague Marta Kalytovska published Two Scales-Two Measures (1972), a collection of her short stories, and her memoirs, titled A Book about My Father: From My Childhood (1977). ${ }^{3}$

Sophia Yablonska's works still remain outside the literary canon, largely because they are atypical for Ukrainian interwar literature, which is primarily represented by poetry and the novel. ${ }^{5}$ She also remains outside European (and more widely, Western) cultural discourse. The Ukrainian language of her travelogues has made them inaccessible to Western readers and researchers, but this is also what makes them unique: if the travelogue is usually viewed as a text "in-between two worlds," Yablonska's work appears in a cultural triangle, at the intersection of the Western (imperial) culture she represented while working for a French film company; the non-European cultures she describes in her travelogues; and Ukrainian culture, which belongs to the European tradition but remained stateless in the interwar period. ${ }^{6}$

When she chose to address Ukrainian readers, Yablonska was forced, literally, to invent the language of her narrative. Due to historical circumstances, she never had the opportunity to be educated in Ukrainian. ${ }^{7}$ After studies in Russian at a women's gymnasium in Taganrog, Yablonska trained in Lviv as a teacher and in drama-in both cases her instruction was in Polish. She graduated from a one-year business course for women organized by the State Academy of Commerce in Lviv. The knowledge she gained helped her start her first business (she operated two cinemas owned by her older brother in the Galician city of Ternopil) and make her own money on a trip to Paris. ${ }^{8}$

However, she faced not only the need to name the different natural and cultural phenomena she encountered while traveling (in the sense of language) but also the need to define, evaluate, and conceptualize them discursively, and her previous education did not give her any of the necessary skills. As she began her travels from Europe in the direction of the East, Yablonska was partly exposed to the stereotypes and prejudices of an imperial perspective, but at the same time she shared the utopian dreams of a stateless nation. And both of these perspectives were challenged by her personal experience, which varied from her first naïve impressions to the experience that came with years of living in different cultural environments. She not only had to invent her own way of storytelling, but also to determine her own place in the stories being told by seeking answers to questions about personal identification and cultural belonging.

\section{Waiting for a Novel}

The post-Soviet version of the history of literature, which also includes Ukrainain literature, is still influenced by the socialist realist model dominated by the idea that the novel is the central literary genre and that it develops one overarching "master plot" (not only in the aesthetic, but especially in the ideological sense), supported by poetry as a myth-creating type of writing. ${ }^{9}$ Indeed, Milan Kundera, in his article "The Tragedy of Central Europe" (1984), describes the novel as a culture-defining genre, a marker of cultural identity. But although he talks about the Poles, the Czechs, the Slovaks, and the Hungarians, Kundera bypasses Ukrainian culture of the interwar period, mention- 
ing in a note that it "is slowly disappearing" through assimilation and unification. ${ }^{10}$ The absence of a novel that could represent national literature in the European canon, or rather, a lack of relevant information and timely translations, is seen as evidence of the absence of literature itself.

The newest projects of literary history that include Ukrainian literature of the interwar period are usually focused on the novel or, more broadly, prose fiction. The innovative History of the Literary Cultures of East-Central Europe, edited by Marcel Cornis-Pope and John Neubauer, characterizes the novelist Mykola Khvyl'ovyi as the most prominent representative of his generation of Ukrainian writers. ${ }^{11}$ However, the novel is not always the only important representative literary genre, especially in conditions that do not contribute to the creation and distribution of long-form prose. Moreover, the form of works in peripheral genres is not as strictly regulated as in the novel, and therefore more flexibly reflects particular individual and collective experiences. The first attempts to question a traditional approach have only recently emerged in Ukrainian studies. Marko Robert Stech, in his preface to the anthology Ukrajina, davaj, Ukrajina! (Ukraine, come on, Ukraine!), explains the key role of short stories for fragmented societies and submerged population groups (both of these terms are borrowed from Frank $\mathrm{O}^{\prime}$ Connor). ${ }^{12}$ In this way he undermines the hegemony of the novel and draws attention to literary forms that correspond to a particular literary situation.

The documentary works of Sophia Yablonska remain on the periphery of Ukrainian literature of the 1930s if for no other reason than that travelogues did not belong to

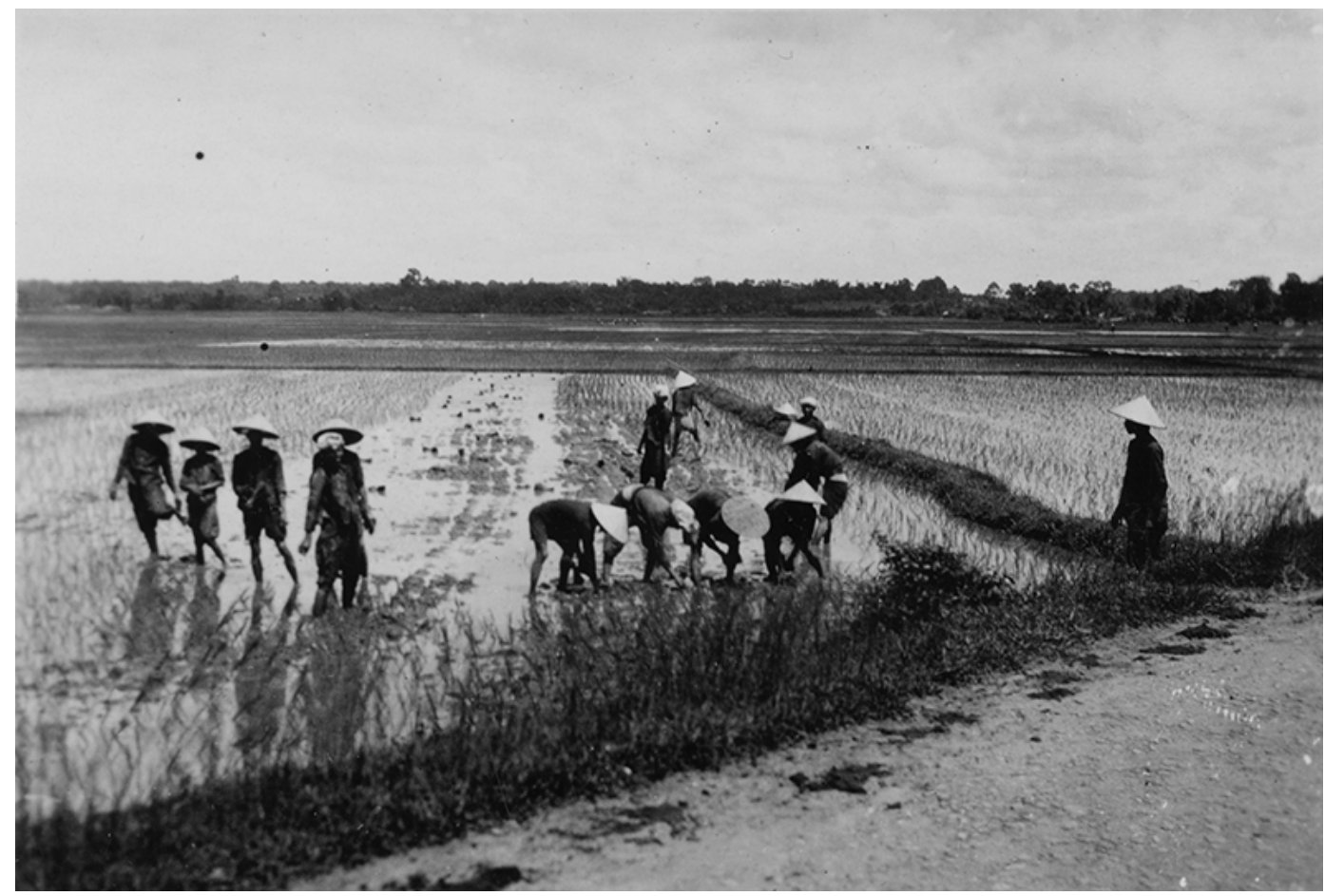

Figure 2: Sophia Yablonska. From her trip to Southeast Asia. 
the main genres of the literary hierarchy of that time. Contemporaries who admired Yablonska's writings saw the promise of a great novel in her journal publications and books. The famous Ukrainian writer and politician Volodymyr Vynnychenko, whom Yablonska met in Paris and who was the first person she shared her writings with, described her works as nothing more than notes, and viewed her travelogues as a result of her failure to write "great literary and artistic works."13 Influential literary critic Mykhailo Rudnytskyi, who supported the publication of Yablonska's works, nevertheless encouraged her as a talented author "with such imagination and dynamics" to write a novel as "a new and higher genre." ${ }^{14}$ Following Rudnytskyi, the wellknown writer Iryna Vilde suggested that Yablonska use her travel experiences to write a novel, as did Pearl Buck, who received the Nobel Prize for her novels about "Chinese life."15 After Yablonska's death in 1971, Marta Kalytovska called her works "reportage stories."16 Several years later, Yuri Klynovyi's review of A Book about My Father classified the work as a transition from reportage to a psychological story, trying to place it among traditionally recognized genres (although the author herself defines her writings as a memoir). ${ }^{17}$

In analyzing Yablonska's works, twentieth-century literary critics hesitated regarding genre definitions and argued about their literary status, using such designations as "travel descriptions," "travel literature," "descriptions of travel" and "memories of a journey," "a book of road impressions," and "memories of the road."18 The authors of more detailed research have chosen between the genres of essay and reportage. ${ }^{19}$ Poet and iconographer Sviatoslav Hordynskyi considers Yablonska's work to be "something more than simple notes and memoirs."20

The views of contemporary literary scholars have also been divided. Researchers seeking the most accurate definition of the genre of Yablonska's writings, which they locate on the verge between literature and documentary, describe them variously as romantic adventure stories and literary and journalistic essays/reports, as prose reportage, travel essays, essays, adventure books, books of essays, and documentary travel novels, or nonfiction travel literature. ${ }^{21}$ All these definitions classify Yablonska's works as exotic-not in terms of theme, but according to the characterictics of the genre. In the classical genre hierarchy this is a marginal form, and therefore does not belong to the literary canon..$^{22}$ What is more, even among different varieties of "travel culture," the concept of women's travelogue still "represents a relatively unknown quantity." 23 That is why the publishers of the latest edition of Yablonska's travelogues consistently call them novels. ${ }^{24}$ This choice is not analytical, but pragmatic, designed to ensure the popularity of the works by responding to readers' expectations.

In the last decade, however, researchers have begun to emphasize the special role of travelogues in modern literature. ${ }^{25}$ Descriptions of real and imagined travel have played an important role in literature for centuries; traveling has been used both as an existential opportunity to gain experience and self-understanding, and as a technical means of changing the place and action in a work. However, as Joyce Kelley notes in Excursions into Modernism: Women Writers, Travel, and the Body, "particularly for modernist writers, ... travel provided a new venue, a new muse ... travel writers of the early decades of the twentieth century reveal the extent to which travel allows for new conceptions of the self, opportunities for imaginative thought, and experimentation 


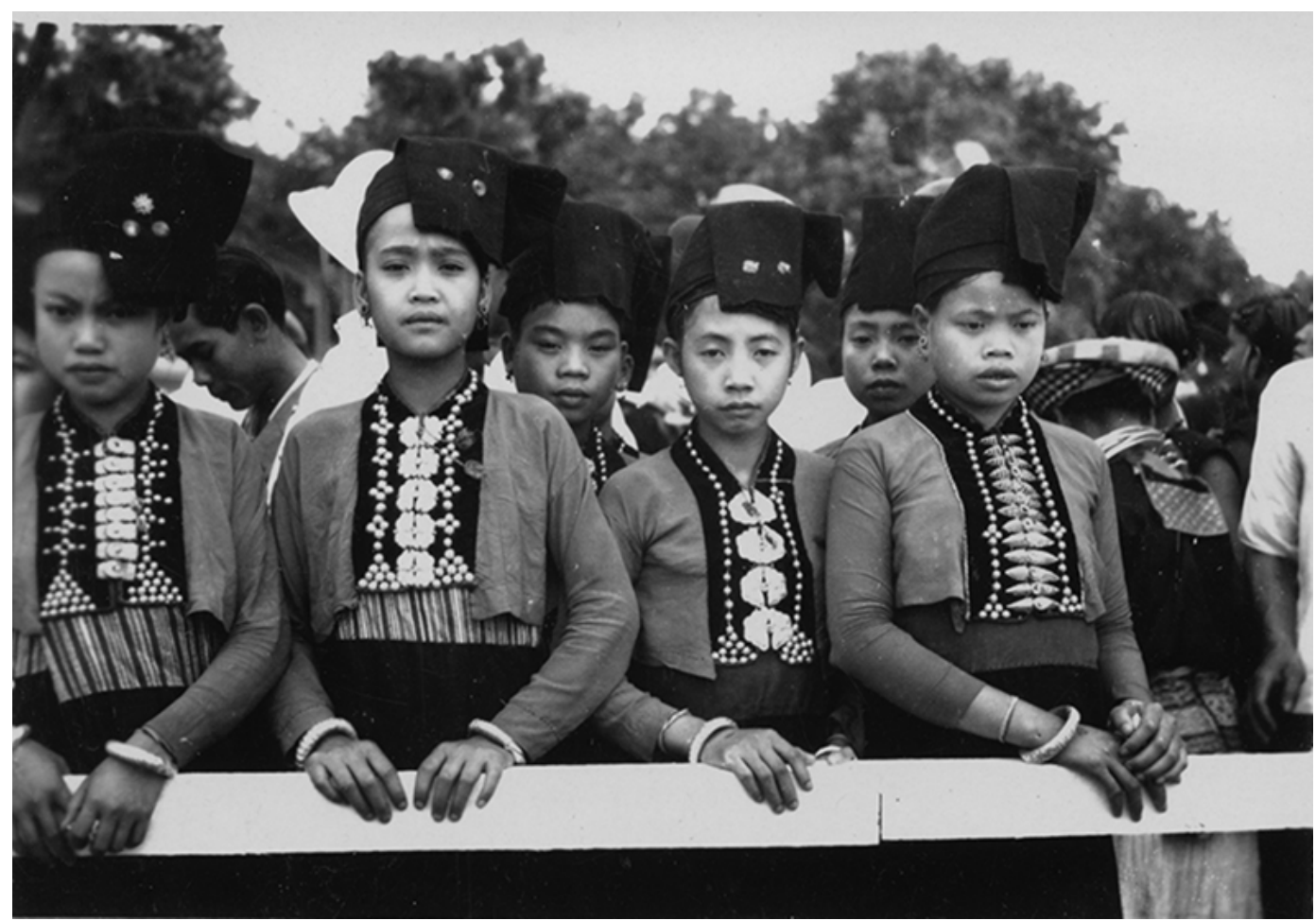

Figure 3: Sophia Yablonska. From her trip to Southeast Asia. Tay or Black Thai girls.

with literary form and language." 26 She argues that travelogues belong as much to travel literature as do fiction travel stories. But what differentiates Yablonska from the authors that Joyce Kelley analyzed is the starting point of her travel in both a geographical and a symbolic sense: she did not leave her "comfort zone," but instead the turbulent marginal territory of interwar Europe, which problemizes rather than establishes her cultural and national identification. ${ }^{27}$

\section{The Voice of the "Second Sex"}

Even in a period of modernization and emancipation, two world wars, and the disintegration and formation of countries and ideologies, there were fewer female than male models of cultural activity in Ukrainian literature. Among forty-one authors mentioned in Rozstriliane vidrodzhennia (Executed Renaissance) by Yurii Lavrinenko (1959), the most famous anthology of the period 1917-1933, not a single woman appears. ${ }^{28}$ Bohdan Kravtsiv includes only two female poets, Ladia Mohylnytska and Olena Teliha, together with forty men, in the anthology Obirvani struny (Broken strings) (1955), which also represents this period. ${ }^{29}$ Ukrainska mala proza XX stolittia (Ukrainian short fiction of the twentieth century), compiled by Vira Aheieva, includes only Iryna Vilde, Lesia Ukrainka, and Olha Kobylanska, who open the century, and Oksana Zabuzhko, who closes it (meanwhile, it also includes the works of twenty-four male authors). ${ }^{30}$ 


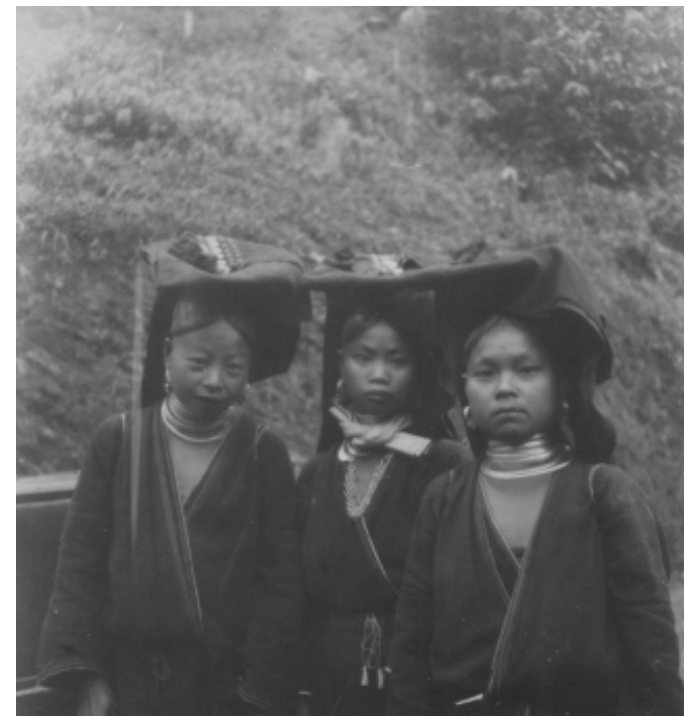

Figure 4: Sophia Yablonska. From her trip to Southeast Asia. Likely, Red Dao girls.
Ukrainain travel writing of the interwar period was not included in these anthologies, but more recent publications show the absence of women in this area as well. ${ }^{31}$ But still, the development of this genre occurred in Soviet Ukraine in the 1920s, when Ukrainian authors published books about their travels to China, Mongolia, Egypt, Persia (now Iran), Ceylon (now Sri Lanka), India, Norway, Italy, and even the Arctic. However, in the second half of the 1930s many of them were arrested and executed, and their works were forbidden by Soviet authorities. Therefore, Sophia Yablonska did not have the opportunity to use their literary achievements. Instead, she was inspired to write travelogues by Ukrainian orientalist Stephan Levynsky (whom she met in Paris, and who published several books on Japanese culture) and Parisian artist Christian Caillard, who traveled to Morocco. ${ }^{32}$ At the beginning of her writing career she appealed to acclaimed critics such as Vynnycheko and Rudnytskyi, but her first publications also attracted the attention of women's organizations in western Ukraine.

In her book on the Ukrainian women's movement in Galicia (where the Ukrainian Women Union alone had over 45,000 members), Martha Bohachevsky-Chomiak states that "post-war women were more independent than their predecessors. . . . Those who were not yet used to public work and public speaking learned quickly and readily from other women. A few of the leaders came from families that valued the education of women, and a number were professional women." ${ }^{33}$ Yablonska appealed to these educated, professional women, who read her works in the women's magazines Zhinocha dolia (Women's fate) and Nova khata (New house) and listened to the public lectures she gave at meetings of women's organizations when she arrived in Galicia on her return from China. Olena Kysilevska, who led the Ukrainian women's movement in Galicia and was a senator in the Senate of the Republic of Poland (1929-1935), traveled to Marrakesh inspired by Yablonska.

Despite Yablonska's popularity, her lifestyle as well as her writing were seen as very unusual and even challenging for Galicia at that time. Sarcastic comments about her appeared in Ukrainian and Polish periodicals. ${ }^{34}$ Eventually, her French employer sent a letter to the Polish newspaper Lwowski ilustrowany express wieczorny (Lviv illustrated evening express), denying any moral transgressions and certifying her high standards and achievements. ${ }^{35}$ Taras Prokhasko argues that "in the interwar decades, Galician literature interpreted life in different ways-as service, as order, as suffering, as struggle, as hopelessness, as patience, as a sacrifice, as a joke, as boredom. That is why Sophia Yablonska, who allowed herself what everyone wanted but forbade her/ himself, caused such delight and condemnation." 36 
From the perspective of the twenty-first century, Sophia Yablonska impresses both with her work and her life story. Perhaps one of the most serious challenges she faced was the conviction that "what is feminine is an enclave reserved for the feminine." 37 But Svoboda Dimitrova-Moeck emphasizes that at the same time "the expansion of the mass media, along with other forces of social and capitalist development, ... precipitated the unparalleled involvement of women in the production of cultural texts, including travel texts," in the interwar period. ${ }^{38}$

If we read Yablonska's travelogues from an anthropological perspective as evidence of a meeting with the Other (other cultures, peoples, patterns, life

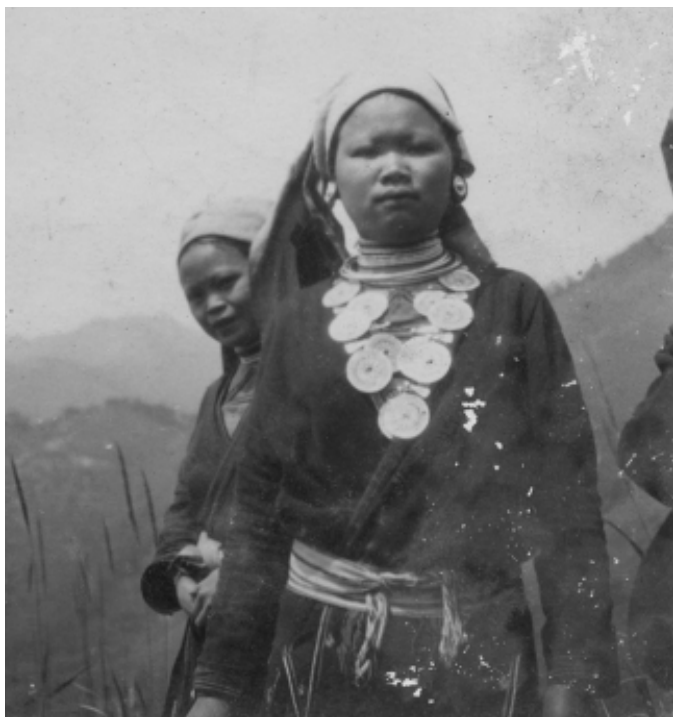

Figure 5: Sophia Yablonska. From her trip to Southeast Asia. Yao Tien women. strategies, and narratives), they not only enrich Ukrainian literature, but also place it within the Western cultural context, in which the voices of female authors resonated persuasively at that time. Female travel writings and anthropological observations (in the broad sense, as the discovery of cultural differences and the recording of testimonies), which did not always correspond to established norms and patterns, were also "a recognition of and a response to the fact that definitions of achievements are often idiosyncratic and reflections of current ideology" and inspired "rethinking the usual criteria for significance." ${ }^{39}$ According to Sidonie Smith, despite the fact that "women have always been and continue to be on the move, ... travel has generally been associated with men and masculine prerogatives" and has "functioned as a domain of constitutive masculinity." 40 Thus, not only in traveling but also in articulating their travel experiences, women were forced to invent new narrative models, introduce new forms of intercultural communication, attract new interlocutors, and touch on topics that had not been addressed before. Dúnlaith Bird even proposes introducing "the original concept of vagabondage" to travelogue studies "as a means of reconceptualizing textual innovation in women's travel writing from 1850, linking physical movement, geographical context, and textual creation." 41

Yablonska's first travelogue (The Charm of Morocco) describes both the situations that drew the author's attention and the interactions in which she was involved, and the first such interaction is related to her perception as a woman. She describes a scene in which an Arab man believed her to be a boy in disguise because of her nonfemale behavior (including playing chess). But her gender gave her an advantage; when her interlocutor realized his mistake she received an invitation to visit the harem. Yablonska comments: "For the first time today I am glad to have been born a woman, because European men have never had the chance to look at the inaccessible secrets of the harem." 42 During these visits Yablonska finds herself in an unusual situation: as a woman, she is allowed access to a harem, but as a European, 
she is an observer, discussing the women in the harem with a man. Her status as a traveler allows her to view foreign cultures through both male expectations and female realities.

\section{The Voice from the "Second World"}

Unlike her American and Western European colleagues, Yablonska as an Eastern European/Ukrainian (and Ukrainian-language) writer speaks not only with the voice of the "second sex," but also with the voice of the colonized and oppressed "Second World." To some extent, her travel was caused by personal and collective trauma, experienced in both cases as a loss of home-as a child she was forced to leave her family home during the war, and the Ukrainian attempts of 1917-1921 to gain statehood failed, leaving Ukraine absent from the political map of Europe. ${ }^{43}$ In 1937, answering a writer's questionnaire, Yablonska affirmed: "I still don't have a real home."44 Two years later, Soviet and then Nazi troops occupied Galicia and Lviv (after the Yalta Conference, eastern Galicia became part of the Soviet Union); Yablonska was never able to visit her native land again. In one of her letters, she mentions that she kept three things throughout her travels: a traditional doll presented to her by women during her lectures in 1939 in Lviv; a collection of poetry by the most famous Ukrainian poet of the nineteenth century, Taras Shevchenko "Kobzar" (The bard); and a small bowl with an inscription expressing hospitality, which could be translated from Ukrainian as "Make yourself at home." 45 They seem to represent three important things: gender, national identity, and the desire for home.

Starting with the first pages of her travelogues, Yablonska consciously presents herself as a person from nowhere. Describing her visit to the harem, she relates her

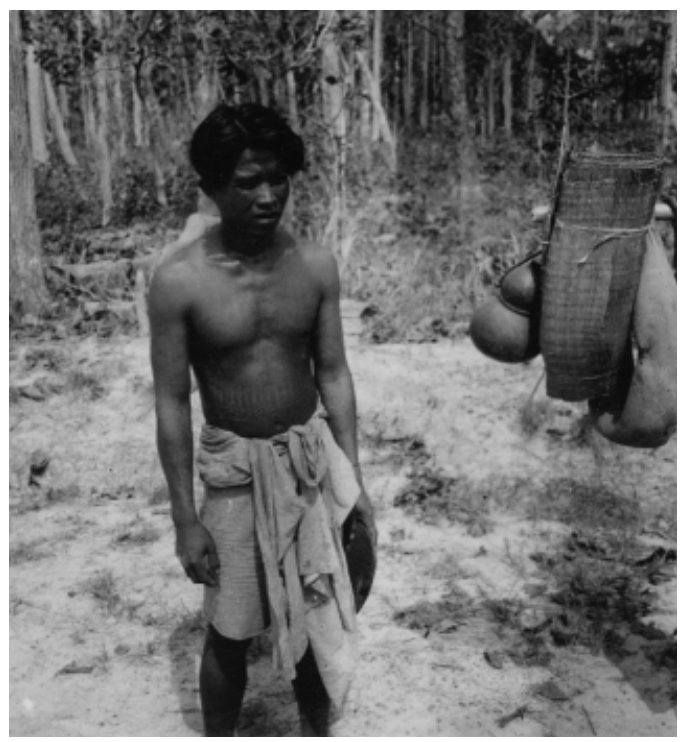

Figure 6: Sophia Yablonska. From her trip to Southeast Asia. conversation with the host: "I started explaining to him the difference between us and the Russians, drew a map of Ukraine and its neighbor countries, so that he better understood its location, eventually I told him that there were around forty million of us and that Ukraine was one and a half times bigger than France. All these explanations I know better than a prayer, because I often have to repeat them to French and other strangers who know nothing about our existence." 46 However, when she traveled, local people tended to perceive her as a representative of French colonial power who spoke the French language and was protected by the colonial administration. Moreover, the situation was further complicated by the movie camera, which was perceived as an un- 
known threat. Yablonska notes that "every Yunnan resident considers a meeting with a European to be a bad sign. And even more so when it's a European with some weird machine looking at them with its shiny eyes." 47

Her dual status, as both sensitive to oppression and possessing the benefits and opportunities of "Western" civilization such as professional education and work for a French film company, forced Yablonska to develop a unique perspective in her views and narration. She is struck by the arrogant attitude of the French toward the Arabs, but at the same time she characterizes the Arabs as "wild, free and passionate children," and this, too, can be seen as the arrogance of the "civilized" and "adult" worlds over the "wild" and "childish" cultures. ${ }^{48}$ By contrast, a French official called Yablonska "the wild Ukrainian,"49 and she recognizes the appellation, thus positioning herself in line with nonimperial cultures and opposing the colonial administration.

Yablonska does not completely avoid exoticization, especially in her first publication. Encountering non-European cultures for the first time, she describes rarities that catch her attention: fire-swallowers, a snake eater, a Senegalese dancer, or a Berber fabulist performing on a central square. Arriving in Morocco, she focuses on unusual events that affect her in the public space of Marrakesh, while passing over the everyday life of the inhabitants. However, the situation gradually changes. Yablonska tries to avoid a shallow view of her surroundings and is critical of the superficial perception that tourists have of the countries they visit: "I still don't like tourists. Why? Because they capture the beauty of Marrakesh with their silhouettes, and their cameras breathe black spots on the clear walls of buildings." 50

Not only does Yablonska avoid tourist routes and guides, she leaves the area of French administrative control many times, looking not for safety but for experience not mediated by imperial and colonial relations. When describing her first visit to China, she contrasts her direct impressions with common perceptions and stereotypes. In her travels to China, Yablonska settles in areas surrounded by local people (rather than representatives of colonial administration), communicates with them, and asks for their opinions and interpretations. Yablonska also reflects upon her own stereotypes and the way they changed with experience. Before her travels she saw the Chinese as "a symbol of timidity, slyness and betrayal"; once she had traveled to China so as to "see the Chinese in order to get to know their life, customs, art, [and] belief," her view changed. ${ }^{51}$

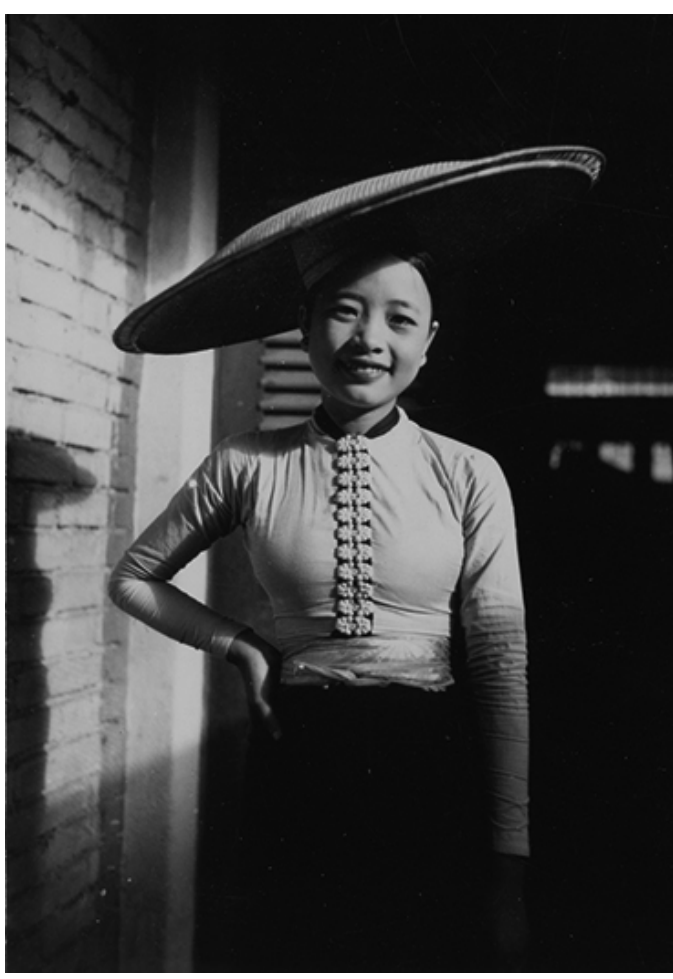

Figure 7: Sophia Yablonska. From her trip to Southeast Asia. Chinese woman. 
This new experience not only enriched her with new knowledge, but also convinced her to abandon Western universalism: "Europe is too far away to serve us here with its example or punish us with its laws." 52 These words can be read as a leitmotif to Yablonska's entire Chinese narrative because they open up the conversation about cultural differences and intercultural communication. Yablonska also avoids the naïve romanticization and idealization of the "non-Western" world; she addresses not only national but also social discrimination. There are no "innocents" among the representatives of the different cultures she describes. Social inequality exists not only between imperial and colonized cultures but also within each of them.

Beyond her constant interest in cultural characteristics and differences, Yablonska also uses other cultures as a mirror to understand her own culture. Describing, for example, the Lolo people in Yunnan, she raises the question of cultural assimilation. Despite the fact that she defines herself as "a person who wants independence for her enslaved country, and a person who wants to defend her language, her tradition, her people," Yablonska sees a complicated dilemma made up of comfort under alien domination and a risky struggle for independence. ${ }^{53}$

\section{Travelogue as Autonarration}

For Yablonska, the choice of an autobiographic form of narration (not only on a cultural but also on a personal level) is not an accidental one. Describing travelogue as a specific type of writing, Alexander Etkind points to its dual nature: "The traveler is looking for the Other; the writer tells about him/herself." ${ }^{14}$ But in the anthropological science of that time, functionalism prevailed and structuralism was becoming more prevalent-both tended to eliminate everything that was subjective or unique. This means that authors of key anthropological works of this period tried not to reveal their presence in the text, and genres such as travelogues, memoirs, diaries, and other forms of autobiographic narration were marginalized. In particular, Claude Lévi-Strauss, who is nearly Yablonska's contemporary, published memoirs on his expeditions of the 1930s under the title Tristes tropiques (Sad tropics) only two decades later, and their key role in understanding the anthropological method developed by "the father of structuralism" was fully explained by Clifford Geertz only in 1988, after a change in the anthropological paradigm, by placing the biographical figure of the author and his literary strategy in the center of his system of knowledge.

Women writers have played a significant role in this process of developing socalled hybrid genres that combine anthropological and autobiographical elements. For Rita Felski, this blurring of fiction and documentary in feminist literature is caused by the very situation of writing. She explains: "Feminist confession exemplifies the intersection between the autobiographical imperative to communicate the truth of unique individuality, and the feminist concern with the representative and intersubjective elements of women's experience. ${ }^{\prime 55}$ Maria G. Rewkowicz claims that "autobiography as a literary genre was quite widespread among feminist writers in the 1970s and 1980s." 56 Giving examples such as Kate Millett's Flying (1974) and Sita (1977), Anja Meulenbelt's The Shame Is Over (1980), Alice Killer's An Unknown Woman (1982), and Ann Oakley's 
Taking It Like a Woman (1980), she argues that "these pioneering feminist confessions were full of elements that deliberately problematized the distinction between autobiography and fiction." 57 It was exactly this "problem" that caused controversy in the 1930s regarding the identification of Sophia Yablonska's works with literature. She herself emphasizes the strong personal factor of her writing: "In general, I write only for my own enjoyment and interest. This is probably why I do not write 'literature.'"58

Unlike anthropological research, which has a strict order in terms of discourse and methodology, documentary narration in the first person allowed Yablonska to map not only the external world, but, most of all, her own feelings and changes, the "new impressions" that took her breath away; in some sense her travelogues can be seen as a kind of autoethnography, or even self-mapping. In this way she manifests herself as a modern author, given that modern travelogue is an "autobiographical narrative, which of course is closely related to the authenticity of the genre."59 Within the form of autobiography Yablonska transforms geography into biography, and her meeting with the Other becomes the required condition for formation of a personality that could be defined as a nomadic subject (in Rosi Braidotti's terms), or a translocal subject (in the sense given by Iwona Boruszkowska). ${ }^{60}$

At the very beginning of her travelogue, the author draws attention to the constant search for new and strong sensations, saying "my astonishment from the first impressions was limitless." 61 Emotion and perception prevails over rationalism in Yablonska's perspective of reality. Rhythm, sound, visual image, and action impress and influence the narration. The opening scene of The Charm of Morocco is very revealing in this context: "The train set out to the sun! To the blue sky! At midday! Tuf-fu-fu,

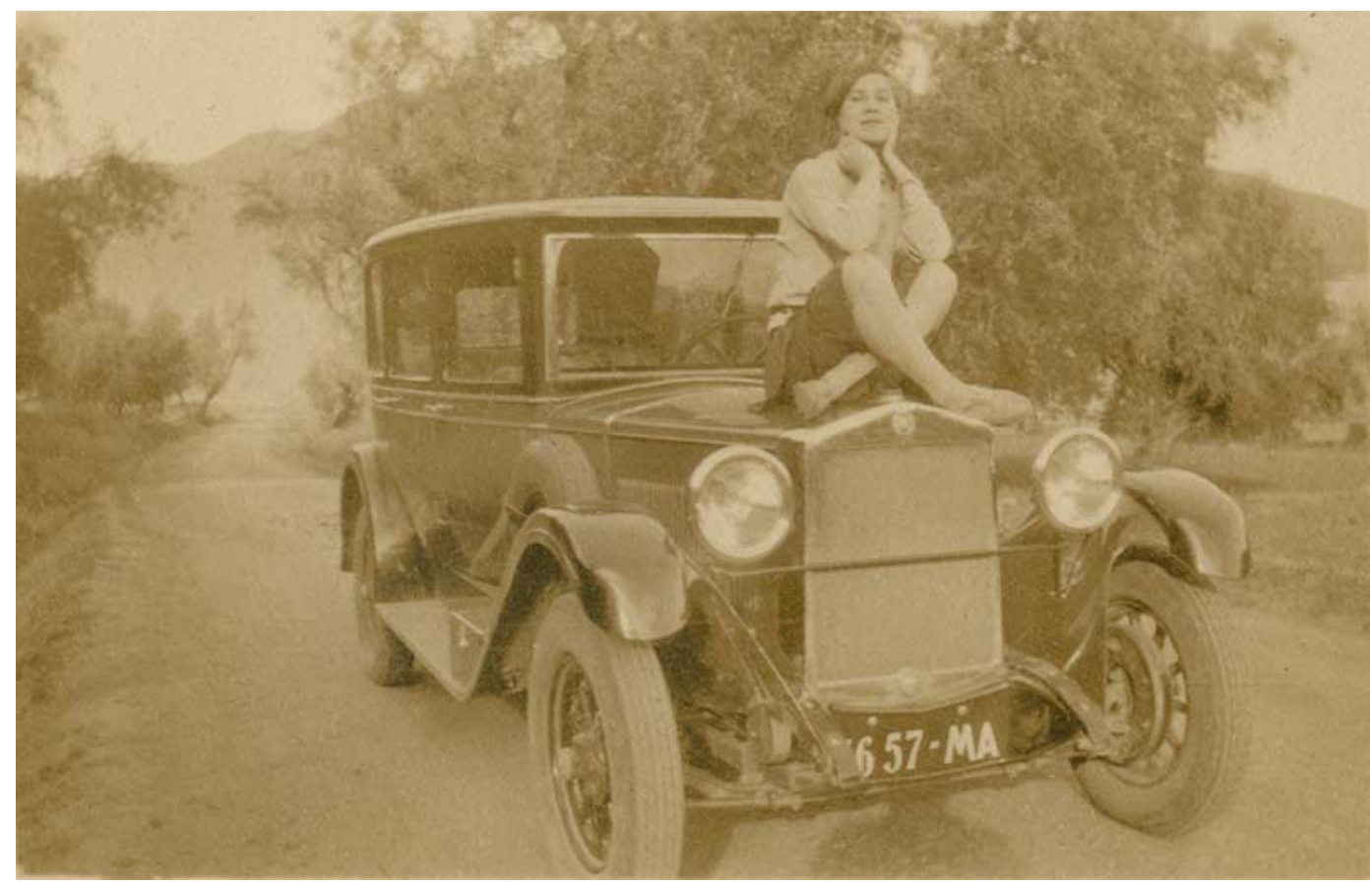

Figure 8: Sophia Yablonska. From her trip to Morocco and Egypt. 
tuf-fu-fu! At midday! The jolly beating of my heart merges with the gay noise of the iron wheels." 62 The melody of a Charleston runs through the entire first part of the story about Marseille. The view, like the one of Marseille from the mountain, plays an important role together with sound. Having arrived in Marrakesh, Yablonska creates a shelter of straw on a building roof in order to watch the panorama of the city from above. She discovers the city by means of images, sounds, and scents: "The wind brings the mixed scent of flowers, vegetables, candles, lamb, and honey. Drunken with the smells, the sounds of monotonous music and the chirping of birds, covered with blue sky, I will draw for you the majestic beauty of Marrakesh and the life of the Arabs." 63

Her exploration of Marrakesh brings strong sensual, physical impressions that occur faster than cognition and conceptualization: "Drunken with these impressions, the strong smell of sweaty bodies, baked lamb, candles, oranges, screaming, dancing, Black and Arabic music, I came back from the Arabic entertainment area. My head is spinning like the wheel of a toy windmill." 64 The author describes the images arising from her busy day until "the room has stopped its drunken dance, only mixed sounds are still creating noise in my ears, the sounds of the Arabic monotonous, the Black ear-splitting music, bells, drums, finger-cymbals, the singing and noise of the mixed crowd." 65

Yablonska even describes a Berber fabulist as a show and a performance; she does not understand his words or care that she does not:

He drew the attention of the spectators with nothing else but his facial expressions and body movements. Many Arabs in the crowd were not able to understand the Berber language. He did not make any odd movement; each one was a logical, smooth accompaniment to his words. This was a perfect flexible dance. He would break the line of his movements or create an accent with the rise of his voice, facial expression, the meaning of his words. He was playing with all the muscles of his body, fingers, finger nails, he even was using the air he exhaled, and he mixed his play with pauses of total immobility, which led to the moments of culmination, taking the spectators' breath away. ${ }^{66}$

The narration of great emotional tension is based on strong impressions. During her later travel to China, Yablonska also showed an interest in faces, facial expressions, and articulation: "The Chinese were stopping, approaching close to my window, lifting their heads up to the light so that I could take pictures up close of their surprised, admiring, smiling, or foolish-looking faces. The expression of their squinting eyes was the most interesting for me." 67

As a modern author, Yablonska talks about the world, expressing her own sensations and emotions. She does not try to hide herself in the text, to create the illusion of objectivity. ${ }^{68}$ But if her first travelogue consists of strong emotional reactions, then in the following works her experiences become deeper and her reactions generate reflection. A literary critique of the time drew attention to this change: "Maybe this kind of female creativity is better? She presents as a new type of woman who is not afraid of losing her primordial feminine features, which are at the same time her greatest weakness-soft- 


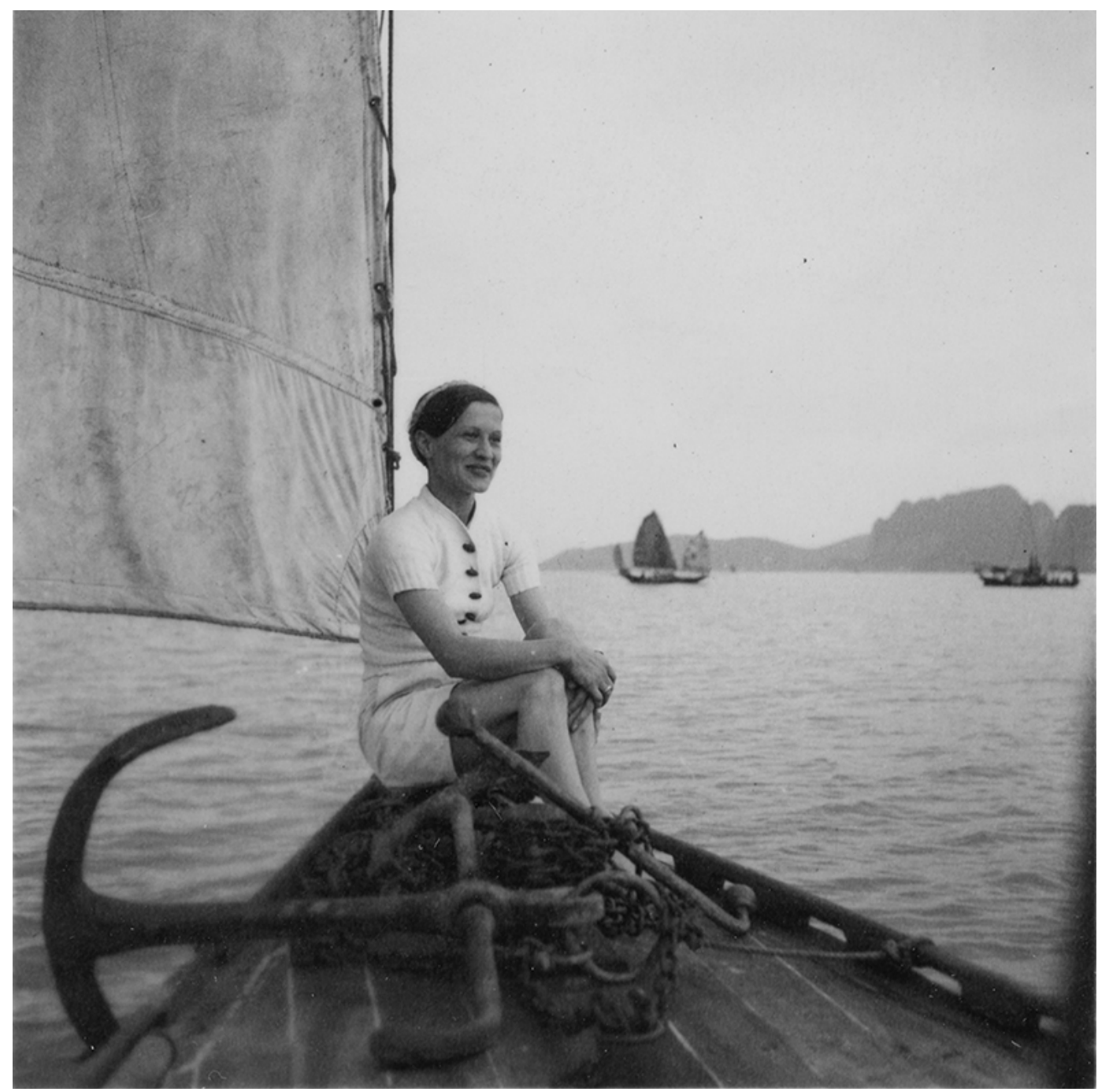

Figure 9: Sophia Yablonska. From her trip to Southeast Asia.

ness and dreaminess. She instead acquires something else-courage and an objective mind. These features, against the backdrop of her typically feminine sensuality, give an interesting and new effect that still has a peculiar feminine charm."

\section{The Limits of Language and the Picture of the World}

In the most intense situations words are imperfect mediators, while pictures instantly fix and transfer expressions that do not need concepts in the process of mediation. As Yablonska describes it: "Such is the strength of impressions, admiration, surprises, such is richness and brightness of colors and forms that I want to take a picture of everything immediately and send it to you instead of writing one word after the other on 
a paper."70 Yablonska's dedication to photography is so strong that only a death threat can stop her; she often puts herself at risk for the sake of photography, especially in those traditional communities that treat photography as the abduction of the human soul. In her texts Yablonska compares the pictures she takes to film and to a dream, which reveals the modern nature of her perception. She was fascinated by movies not only as a technique but also as a symbol of the modern cultural age. Her writing style can be described as cinematic; she prefers to portray situations and dialogues rather than presenting arguments and drawing conclusions.

The movement depicted in her photos is also closely connected with her own movement as a main principle and purpose of her life. Yablonska appears to her readers as a real homo viator, who experiences the world and herself in her travels. "That's why I start my journey over and over again and I still have a long way ahead." She overcomes geographical and cultural distances in order to discover the stories of others, but primarily to live her own as a unique life (and geographical) trajectory: "The insatiable instinct of a quick traveler made me go as far away as possible from the railways, shipping routes, and paved roads."71 In describing her travels, Yablonska demonstrates the becoming of herself as a modern personality.

This formation of a modern personality happens by crossing borders. Yablonska is tempted not only by interest, but also by danger, a meeting with the unknown and uncontrollable. For instance, a visit to a harem in Marrakesh provokes an entire range of feelings: she has "a frightened heart," is "totally confused," feels like "a mouse trapped in a cage," and experiences "fright," "mistrust," and "trust."72 Yablonska is in a similar condition before going to the Sahara: "The smell of danger has already enlarged the compartments of my heart. Interesting! Maybe, this is the last day of my freedom?"73 In the desert she observes: "The danger looks with a hundred of its feverish eyes, drags me to itself and attracts me."74 The deeper Yablonska dives into the unknown world the greater risk she is exposed to: from the closed space of the harem to the open space of the desert with the scorching sun and nomads on camels, who threaten her with death or captivity. This "pointless" escape to the Sahara is shocking both for the "civilized" Frenchmen and the "naïve" Berbers. She makes this journey neither for professional purposes nor for enjoyment, so the only aim remains new experience and presence, the search for a border not only in the external world but also in an internal one. Yablonska needs new sensations in order to explore her own limits and is afraid of getting used to any deep impression.

Yablonska does not limit herself to psychological self-observation. In examining the cultural relativity of feelings and emotions, she concludes that "my European 'white' sensitivity plays a great role in my observing, because the Chinese, set in their traditions, perceive life and its manifestations in a totally different way."75 Thus, the ability to feel empathy does not mean accepting the worldview of those people with whom we empathize. On the contrary, she concludes that excessive empathy is a specifically European cultural phenomenon that differentiates the European observer from the local people. Yablonska tells two stories: how she fed a skinny, homeless dog, and how she paid a woman who sold her young son out of desperation and need. She had to take both the dog and the boy home. After this she tried to bypass such situations, recognizing that she was "weaker than them" when compared to local people. ${ }^{76}$ 


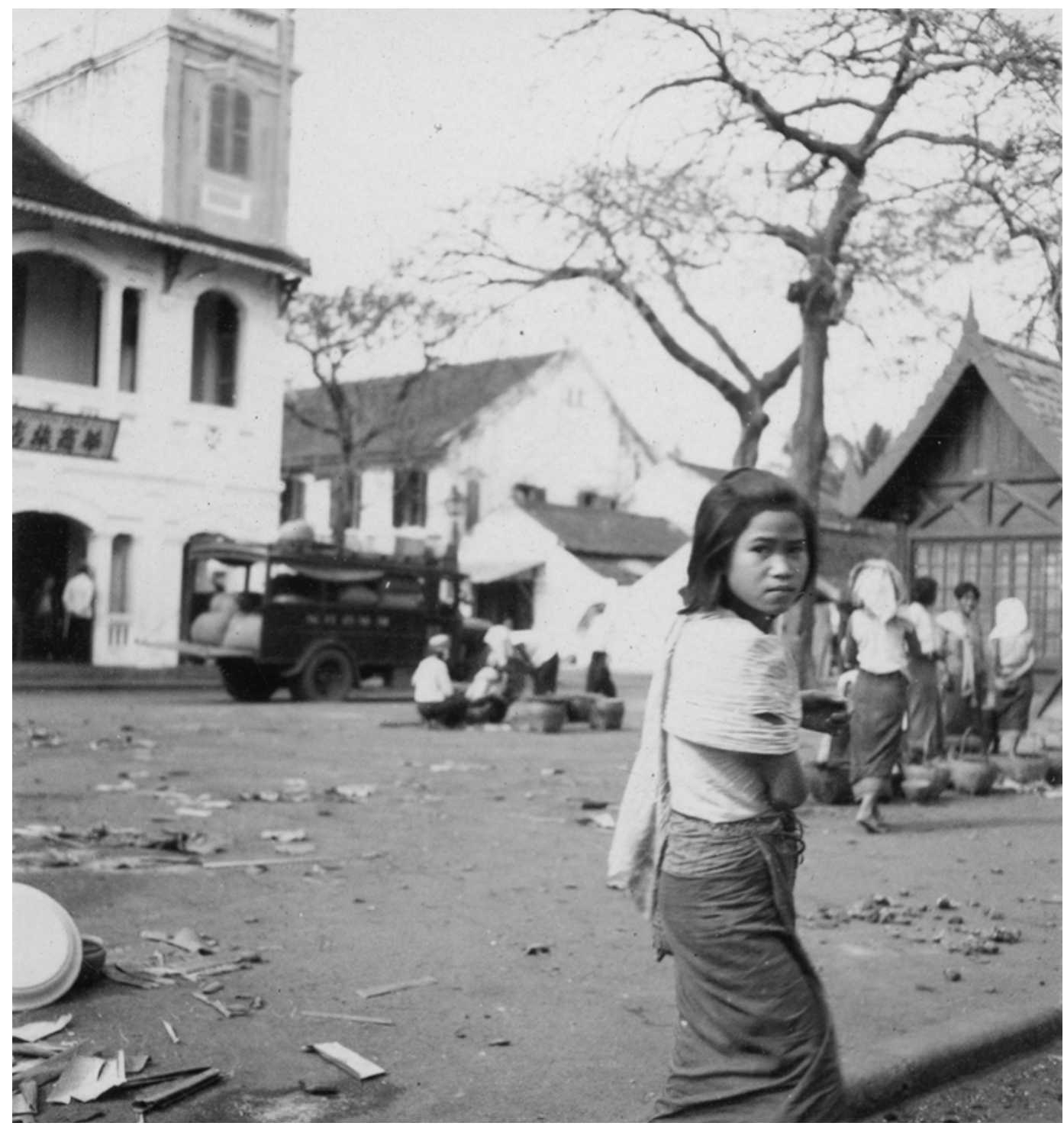

Figure 10: Sophia Yablonska. From her trip to Southeast Asia. Most likely, Cambodia.

Yablonska vividly presents the difference between modern and traditional sensitivity in her understanding of beauty and death. From the first pages of her Chinese travelogue Yablonska focuses on the problem of the connection between suffering and beauty. These thoughts were induced by the strong impression made on her by women with bound feet. "Any beauty, Miss, costs us some suffering" - these words, spoken by her companion on a train, play one of the key roles in the entire narrative. ${ }^{77}$ Moreover, Yablonska returns several times to this topic. According to the Chinese people, she suggests, "beauty shall not impress us with its variety, its value lies namely in the stability and tireless repetition of the same colors, impressions, and forms."78 She addresses this topic again in a conversation about traditional Chinese theater, regarding 
which her Chinese friend says, "I know that our theater cannot impress you." ${ }^{179} \mathrm{Her}$ friend adds, "It's a pity, our dramatists—-modernists—-do not want to understand this. They are stubborn and are heading toward the 'civilizing' of our theater, they want to give it a European stamp, in other words, to bring into it your required love triangle, or some other romantic intrigues. The Chinese masses will never be satisfied with this." ${ }^{\prime 80}$

Likewise, the understanding of death and the experiences associated with it became one of the main indicators of cultural difference for Yablonska. In one of the Chinese cities she visited, Yablonska lived close to the square where executions were held. But the things that struck her left the Chinese indifferent or even disappointed. She was "surprised with the indifference to the view of those executions." ${ }^{11}$ Eventually, she concluded that "these are two different worlds separated by centuries, different traditions, worldviews, climate, even a different skin color, by everything. Even if I could understand their world of feelings it does not mean that I would agree with it." 82

But the experience of living on the border between an old (conservative) and a young (dynamic) culture leaves its mark. Yablonska's publications reveal an implicit discussion of the limits of what can be perceived, captured, and described, and what this means about the limits of literature and art. In one episode, she describes a situation in which she did not dare photograph public torture. This time there were no external obstacles, only internal rejection and fear: "I couldn't direct my camera in any way toward the deadly pale face of a pirate" subjected to public execution. ${ }^{83}$ Nevertheless, one of her next chapters contains her photo showing the death of "a person sentenced to execution by strangulation" and the cut-off heads of two pirates ${ }^{84}$ In this case, the visual picture is not a direct illustration of the text. Quite the opposite: these "impossible" photographs deny what she claims in the text and thus create a dilemma for readers to solve on their own. However, she does not explain what exactly influenced her change of decision. The first time this episode is published (in a magazine), Yablonska warns that the visual images may be disturbing to some readers. Readers are forced to decide for themselves from what position they can (or if they can) contemplate such scenes.

Reaching the border of her own language (the ability to express her personal experience) in this way, Yablonska comes to understand the relativity of the notion of "culture" in its Western interpretation:

Culture, as I see it, is a totally unstable notion. In the eyes of the Chinese, we are wild, ignorant people, even people without a soul, without thought.... The Chinese treat our civilization, our inventions, our progress as empty things without any durability, any sense, despite the fact that they need them sometimes for themselves. "Your inventions haven't enriched your life, just made it more complicated," an old Chinese man said to me. And I am afraid that this time he has told a deep truth. ${ }^{85}$

Eventually, Yablonska crossed linguistic borders in her writing - not only the borders of national languages but also the limits of literary genres as canonized narrative models. In fact, she developed a personal narrative to articulate her own life trajectory: 
her longing for the center of the modern cultural world (Paris) is caused by a wish for centrifugal movement, and the center is not her target but the starting point for a new journey in order to find herself. Although her travels to Morocco and China are driven by the interests of a French film company, she chooses her route around the world on her own. After leaving Marseille she visited Port Said, Djibouti, Colombo, Saigon (now Ho Chi Minh City), Huế, Hanoi (where she lived for three years), Laos, Phnom Penh, Angkor, Bangkok, Penang Island, Singapore, Java Island, Perth, Sydney, Auckland, Lake Waikaremoana, Wellington, and Rarotonga Island. But the true purpose of this journey was the Tahitian island of Bora Bora, which she had dreamed of since childhood. In fact, the very journey in which she was repeatedly threatened and for which she risked personal relationships could be called a return to a childhood dream. She lived on Bora Bora for several months, where she acquired the new name Teura and met famous French

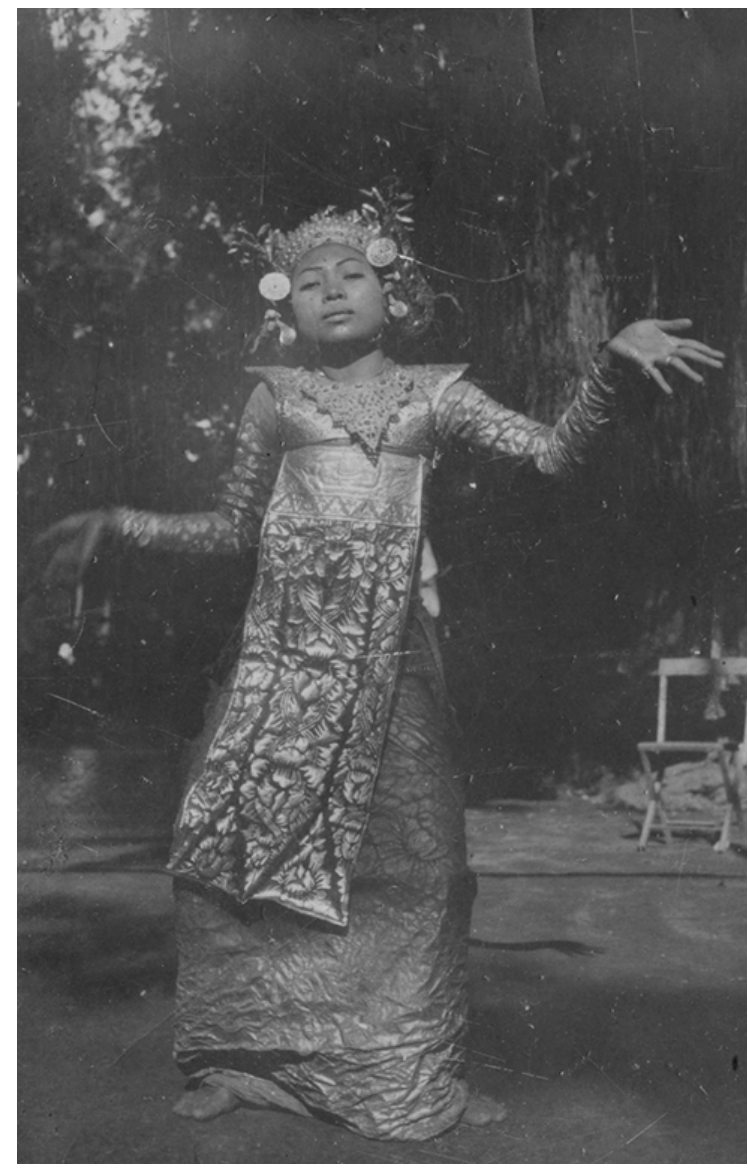

Figure 11: Sophia Yablonska. From her trip to Southeast Asia. Balinese Legong dancer. traveler Alain Gerbault and the actor Matahi, who starred in the docufiction film Tabu: A Story of the South Seas (1931), directed by F. W. Murnau. And although Yablonska returned to Europe via America (San Francisco and New York), she ended her travelogue with her stay at Bora Bora.

\section{Conclusion}

Yablonska has not yet found her proper place in the history of Ukrainian literature, but avoiding strictly determined, canonized literary genres enabled her to convey unique personal and cultural experiences. The travelogue became for her first and foremost a journey into herself. Beginning with an awareness of her own national and gender identity, she finally came to understand how culture determines personality. The final aim of her travel around the world was to return home not only physically, but also symbolically. Her memories of childhood comprise the last scene of her travelogues about life in China, after which the traveler and writer packs her luggage and ends 


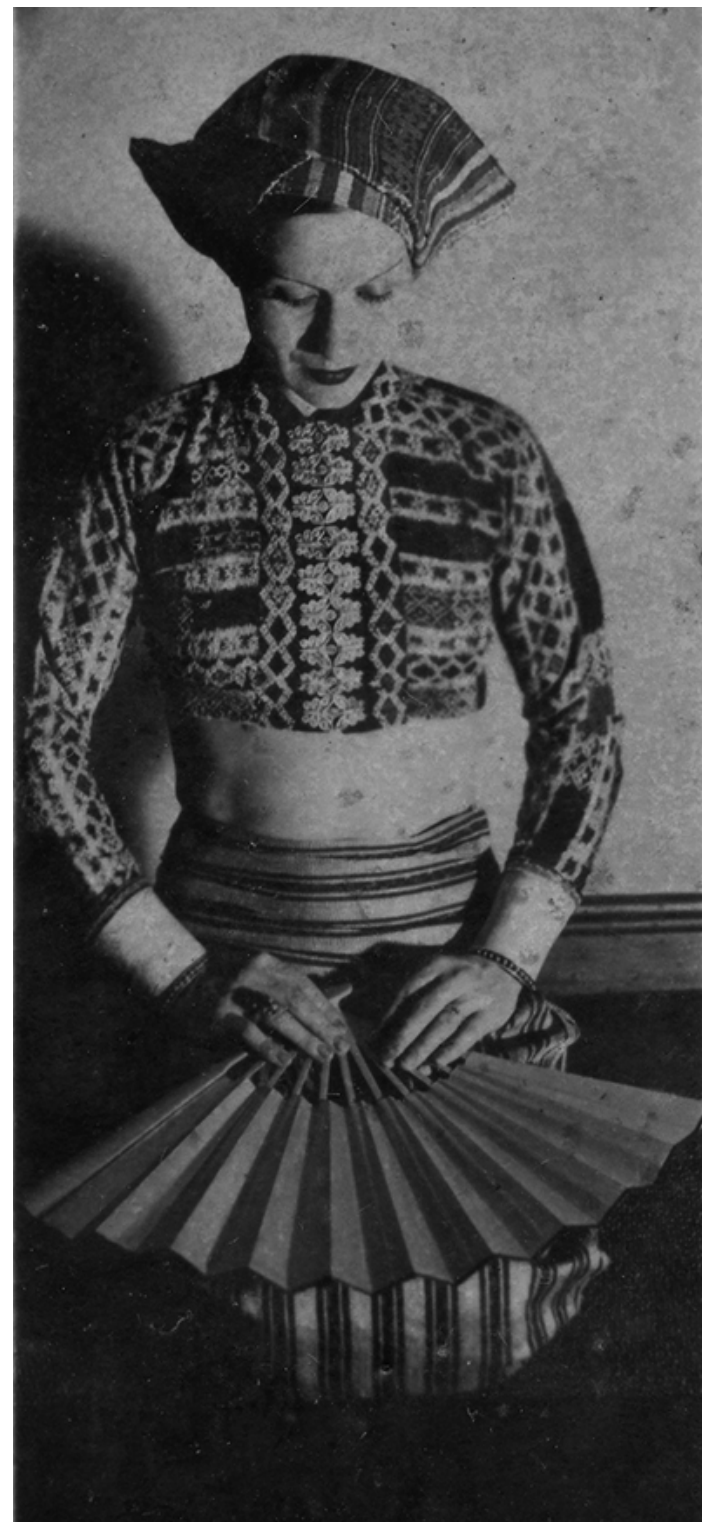

Figure 12: Sophia Yablonska. From her trip to China. the narration. She starts by finding her roots and ends by demonstrating the path to becoming herself. Her writings, which combine anthropological and autobiographical aspects, communicate not only about other countries, but also about the formation of a modern personality in the process of writing. Abandoning the genre of the novel in favor of the travelogue, Sophia Yablonska performed a textual and experiential transgression on several levels: that of genre, gender, the anthropological, the autobiographical, the perceptual, media, culture, and discourse.

In the Ukrainian literature of the interwar period, Yablonska developed a new type of narration that went beyond genre expectations; in the form of travelogue she articulated an experience that is generally absent in nondominant ethnic groups and fragmented societies - as Daria Vikonska, one of the writers and literary critics of the time, notes, "this area for native literature is still painfully wretched." ${ }^{16}$ In addressing her writing to a Ukrainian readership, Yablonska also went beyond the colonizer-colonized dichotomy that was typical for travelogues as a genre of Western literature of the period.

Traveling and living in different cultural areas, Yablonska began to think more deeply about the issue of gender, in particular the position of women in different societies. On the one hand, her experience and lifestyle made her an extremely exciting figure for the women's movement in Galicia/western Ukraine; on the other hand, in communicating with such leading women's activists and writers as Olena Kysilevska, Lidia Burachynska, Iryna Vilde, and others, Yablonska shifted her attention from exceptional situations and "exotic" experiences to the social nature of gender differences; in particular, she discussed the conditions for women's creativity, arguing that "many married women write less and worse, and sometimes even fall silent. This is because whatever family life is, it places the woman, and especially her, face-to-face with daily routine." ${ }^{\prime 87}$ 
Looking for meetings with the Other, Yablonska went not from the center to the periphery, but from the periphery of the Western world to a place not involved in such confrontation. According to her, the purpose of her travels was to see "the countries where people live carelessly and happily, in a completely different way than in our country and in our part of the world"; in the end, she came to see the naïvety and the utopia of her hopes, and arrived at a deeper understanding of the problem: "in my travels, from land to land, I never met the paradise I had hoped for. But sometimes at least a few glimpses of earthly happiness were captured from afar, and now this has more value for me than imagined paradises." 88 An experience of other cultures could become the basis for a new understanding of one's own culture: "I believe that a person can go beyond his/herself-then his/her judgment will become completely different, more uncompromising and more rigorous toward him/herself." 89

In describing different cultures, Yablonska faced the challenge of lacking a language of description. This problem applied not only to the national language but also to discursive practices: she represents Western culture as dominant, but at the same time she associates herself with oppressed groups as a Ukrainian and as a woman. For example, she borrows from colonial discourse such characteristics of others as "wild" and "childish," but also applies them to her own culture; in this way Yablonska challenges the overall value system, and these challenges also correspond to the aesthetic hierarchy of modernism.

In accordance with modernist tendencies, Yablonska places herself at the center of the narrative, reflecting the world through her own sensations, feelings, and experiences. She does not attempt to distance herself from the events she describes, and does not seek objective analysis-on the contrary, she attempts to convey the subjective experience of the moment. Her writing could be defined as an example of autoethnography, which evolves from perception to reflection.

Yablonska departs from the previous tradition of Ukrainian travel literature by changing the way the subject is presented; her writing is photographic and cinematic, "a modern factography against former fabulous and majestic fiction." 90 What is more, the narrative that Yablonska created is not limited to the verbal level; the photographic images that accompany the story in her books do not illustrate the text, but supplement it or even contradict it, and this is also a manifestation of modernism in her trav-

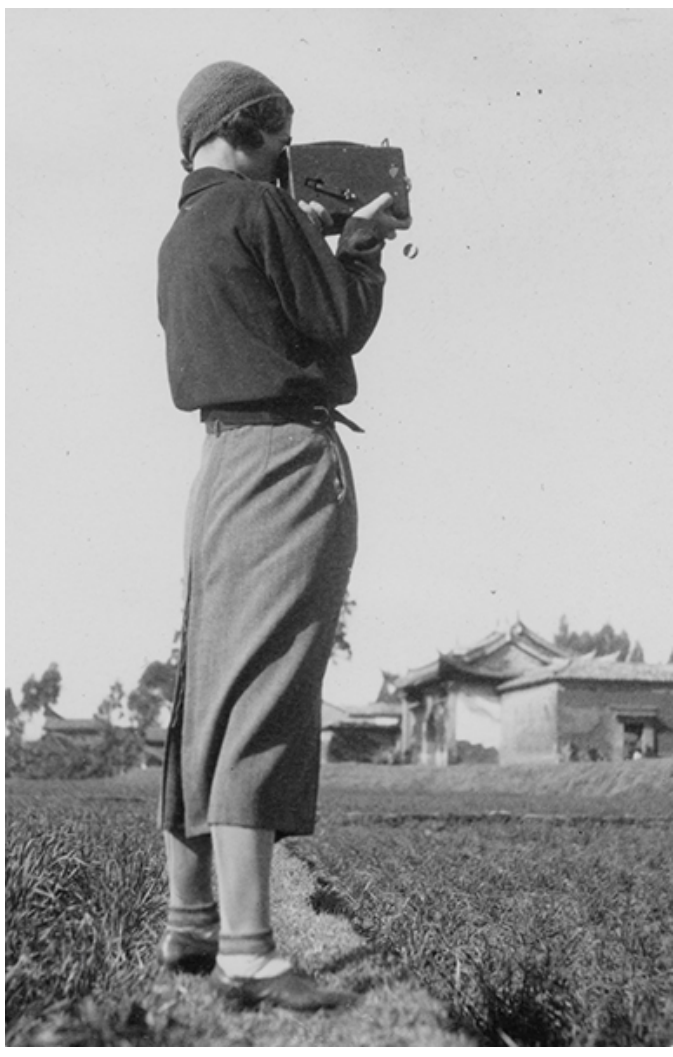

Figure 13: Sophia Yablonska. From her trip to China. 
elogues. In addition, the use of a "hidden camera" allowed Yablonska to change the direction of view in the relationship of observer and observed; through visual imagery, she conveyed impressions that go beyond defined concepts, creating open space for interpretation.

Starting from gender and national self-definition, Yablonska gradually revealed the cultural and historical relativity of not only her own identity but also her own emotions, virtues, and values; she experienced the difference between traditional and modern cultural paradigms, and questioned the undisputed superiority of the second, while remaining, however, its conscious representative. Finally, Yablonska's travelogues problematize the very notion of literature, the distinction between fiction and documentary, and the connection between writing and movement. Her publications in periodicals (which preceded her books) eventually prompted critics to speak about the appearance of literary reportage in the Ukrainian tradition: her writing goes beyond the scope of a reporter's work, rather fitting into what was later called the "new journalism," in which the author combines separate facts into his/her own highly individualized story, trying not so much to inform the reader as to capture them emotionally and thus inspire them to revise their own ideas and stereotypes both about other cultures and about their own cultural identity and belonging.

\section{$\diamond$ About the Author}

Olena Haleta is Professor of Literary Theory at Ivan Franko National University of Lviv, and Professor of Cultural Anthropology at Ukrainian Catholic University. She was a visiting professor at the University of Zagreb, Jagiellonian University, and Humboldt University of Berlin, visiting research fellow at Warsaw University, Toronto University, Harvard University, Vienna University, Monash University, Columbia University, Humboldt University of Berlin, and at the Kennan Institute, Woodrow Wilson International Center for Scholars at Washington DC. She is the author of From Anthology To Ontology: Anthology as a Means of Representation of Ukrainian Literature of the Late Nineteenth-the Early Twenty-First Centuries (2015); the author and editor of Love Experience and Pure Mind Criticism. Valeryan Pidmohylnyi: Texts and the onflict of Interpretations (2003); Valeryan Pidmohylnyi: Programme Texts, Illustrations, Explanations, Tasks, Tests (2001); and the editor of collections of essays (Histories and/of Literatures, 2010; Irony, 2006; Sappho, 2005; Formalism, 2004) and the academic series University Dialogs (since 2007).

\section{$\diamond$ Notes}

1. Yablonska's father, who was a priest and who supported the idea of eastern Slavic unity, traveled with his family during World War I to Russia, but he became disillusioned and returned to western Ukraine a few years later (they crossed the Soviet-Polish border in 1921). Yablonska described the difficulties and challenges of her life in Taganrog in several short stories. For more biographical information, see Marta Kalytovska, "Sofiia Iablonska: Podorozhnyk i liudyna" [Sophia Yablonska: The traveler and person], Suchasnist 5 (May 1971): 51-59; Yuri Klynovyi, "Sofiia Iablonska-ii naikrashchyi tvir" [Sophia Yablonska-her best 
work], Suchasnist 6 (June 1977): 20-27; Fedir Pohrebennyk, "'Char Marokko' ta inshi perlyny" ["The charm of Morocco" and other pearls], Vsesvit 3 (1990): 151; Valentyna Peredyrii, "Svit Sofii Iablonskoi" [Sophia Yablonska's world], Dzvin 8-9 (1998): 98-105; Iaroslav Polishchuk, "Navkolosvitnia mandrivka Sofii Iablonskoi" [The world journey of Sophia Yablonska], Ukrainskyi zhurnal 3 (2007): 6-7; Iaroslav Polishchuk, "Mandrivna Muza Sofii Iablonskoi" [The traveling muse of Sophia Yablonska], in Peizazhi liuduny: Trynadciat istorii zi svitu literatury [Human landscapes: Thirteen stories from the world of literature] (Kharkiv: Acta, 2013), 424-453; Vasyl Gabor, "Chy isnuiut shche des na sviti raiski ostrovy" [Are there paradise islands somewhere in the world], in Lysty z Paryzha, lysty z Kytaiu [Letters from Paris, letters from China], by Sofiia Iablonska (Lviv: LA “Piramida," 2018), 9-15; Vasyl Gabor, "Ekzotychnyi svit, vidchutyi sercem ukrainky: Mozaika" [The exotic world, felt by the heart of Ukrainian women: A mosaic], in Char Maroka, Z krainy ryzhu ta opiu, Daleki obrii [Charm of Morocco, From the country of rice and opium, Distant horizons], by Sofiia Iablonska (Lviv: LA "Piramida," 2015), 7-21; Tetiana Kuzminchuk, "Trevel-'bloggerka' z mynuloho stolittia" [Travel "blogger" from the last century], Lokal'na istoria 1 (2019): 80-85; Oksana Zabuzhko, "Peredmova" [Preface], in Teura: Sofiia Iablonska [Teura: Sophia Yablonska], by Sofiia Iablonska (Kyiv: Rodovid, 2018), 9-18; Veronika Homeniuk and Andrii Benytskyi, "Biografiia" [Biography], in Teura, 210-229.

2. Serhii Plokhy, The Gates of Europe: A History of Ukraine (New York: Basic Books, 2015), 213.

3. Yablonska's works were republished only recently. Vasyl Gabor edited two volumes, Char Maroka, Z krainy ryzhu ta opiu, Daleki obrii [Charm of Morocco, From the country of rice and opium, Distant horizons] and Lysty $z$ Paryzha, lysty z Kytaiu [Letters from Paris, letters from China]; one book was edited by Oksana Antonova: Sofiia Iablonska, Knyha pro bat'ka: Z moho dytynstva [A book about my father: From my childhood] (Kyiv: Bohuslavknyha, 2015); one was published by Oleksandr Savchuk without information about the editor: Sofiia Iablonska, Foto [Photos] (Kyiv: Library of Ukrainian Art, Publisher Oleksandr Savchuk, 2017); four of her works were edited by Veronika Homeniuk and Andrii Benytskyi: Sofiia Iablonska, Char Maroka [Charm of Morocco] (Kyiv: Rodovid, 2018); Z krainy ryzhu ta opiu [From the country of rice and opium] (Kyiv: Rodovid, 2018); Daleki obrii [Distant horizons] (Kyiv: Rodovid, 2018); and Teura: Sofiia Iablonska [Teura: Sophia Yablonska] (Kyiv: Rodovid, 2018). This last is particularly important because it contains archival materials published for the first time (Yablonska's photos and personal documents).

4. Photos included were taken by Sophia Yablonska and are held in the private archive of Natalie Oudin, a granddaughter. Copies are courtesy of Veronika Homeniuk and Andrii Benytskyi. Any reproduction or circulation of these images is forbidden.

5. This issue was raised for the first time at the conference "Imagined Community: Women Writers of Central Europe in the Light of Literary, Social and Political Problems in the Years 1914-1945," with subsequent publication of the roundtable discussion. See Ołena Hałeta, "Historia literatury jako praktyka ponownego czytania" [The history of literature as a practice of re-reading], in Wspólnota wyobrażona: Pisarki Europy Środkowej wobec problemów literackich, społecznych i politycznych lat 1914-1945 [Imagined community: Women writers of Central Europe in the face of literary, social and political problems of 1914-1945], ed. Grażyna Borkowska, Iwona Boruszkowska, and Katarzyna Nadana-Sokołowska (Warsaw: Instytut Badań Literackich PAN, 2017), 501-509.

6. See, e.g., Béatrice Bijon and Gérard Gâcon, eds., In-between Two Worlds: Narratives by Female Explorers and Travellers, 1850-1945 (New York: Peter Lang, 2009), 121.

7. According to Christoph Mick, "In 1920 there were forty-five Polish state primary schools in L'viv but only one Ukrainian state primary school. Ukrainians funded private primary school for 1,580 children, but 1,126 Ukrainian children were obligated to attend Polish schools. 
The only Ukrainian secondary school was given a provisional home in the Ukrainian National House. In 1919 all Ukrainian-language chairs in L'viv University were abolished. The government broke its promise to create a Ukrainian university and tried to suppress the private Ukrainian university, where former Ukrainian professors and lecturers from the main university were teaching." Christoph Mick, Lemberg, Lwów, L'viv, 1914-1947: Violence and Ethnicity in a Contested City (West Lafayette, IN: Purdue University Press, 2016), 215.

8. Homeniuk and Benytskyi, "Biografiia," 210-211. Unless otherwise stated, all translations are mine.

9. See Katerina Clark, The Soviet Novel: History as Ritual (Bloomington: Indiana University Press, 2000).

10. Milan Kundera, "The Tragedy of Central Europe," New York Review of Books, 26 April 1984, 33-38.

11. See Marcel Cornis-Pope and John Neubauer, eds., History of the Literary Cultures of East-Central Europe: Junctures and Disjunctures in the 19th and 20th Centuries (Philadelphia: John Benjamins Publishing Company, 2006), 2:424-425.

12. Marko Robert Stech, "Panorámy postčernobyl'skej ukrajinskej poviedky: Od katastrofy ku katarzii?" [Panoramas of post-Chernobyl Ukrainian short story: From disaster to catharsis?], in Ukrajina, davaj, Ukrajina! [Ukraine, come on, Ukraine!], ed. Marko Robert Stech and Lucie Řehoříková (Prague: Větrné mlýny, 2012), 19.

13. Homeniuk and Benytskyi, "Biografiia," 213, 217.

14. M. R. [Mykhailo Rydnytskyi], "Velykyi reportazh S. Iablonskoi" [A great report by S. Yablonska], Dilo 62 (19 March 1939): 10.

15. I. V., "Sofiia Iablonska: Daleki obrii" [Sophia Yablonska: Distant horizons], Zhinocha dolia 9-10 (1-15 May 1939): 13.

16. Kalytovska, "Sofiia Iablonska," 55.

17. Klynovyi, "Sofiia Iablonska," 23.

18. Daria Vikonska, "Char Maroka" [The charm of Morocco], Zhinocha dolia 28 (15 November 1932): 12; Vikonska, "Sofiia Iablonska: Char Maroka" [Sophia Yablonska: Charm of Morocco], Dazhboh 3 (1933): 60; O. Dniprovskyi, "Talanovyta zemliachka mandruie" [The talented countrywoman travels], Nazustrich 1 (1 January 1934): 7; L. Nyhrytskyi, "Na knyzhkovomu rynky" [On the book market], Novyi chas 173 (3 August 1936): 8; L. B. [Lidia Burachynska], "Sofiia Iablonska: 'Daleki obrii'" [Sophia Yablonska: "Distant horizons"], Nova khata 10 (October 1939): back cover; Oksana Rudchenko, "Moloda zemliachka mandruie po dalerykh moriakh" [A young countrywoman travels in the far seas], Zhinka 9-10 (June 1939): 5, 6.

19. See M. H. [Mykola Hnatyshak], “Ulas Samchuk, Vidnaidenyi rai. Sofiia Iablonska, Z krainy ryzhu ta opiu" [Ulas Samchuk, Paradise regained. Sophia Yablonska, From the country of rice and opium], Dzvony 6-7 (June-July 1936): 276-279; M. R., "Velykyi reportazh," 10; L. B., "Sofiia Iablonska," back cover.

20. Sviatoslav Hordynskyi, "Pani z Kytaiu" [Lady from China], Nazustrich 11 (1 June 1936): 6.

21. See Pohrebennyk, "Char Marokko"; Taras Prokhasko, "Teura-donka vsioho ostrova" [Teura-daughter of the entire island], Halytskyi korespondent, 6 April 2011, http://gk-press .if.ua/x4595/; Dzvinka Vorobkalo, "Istoria halychanky, iaka pobachyla ves svit, abo dyvovyzhni obrii Sofii Iablonskoi" [Story of a Galician, who saw the whole world, or the wonderful horizons of Sophia Yablonska], Fotohrafii staroho L'vova [Photos of the old Lviv], 12 March 2016, http://photo-lviv.in.ua/istoriya-halychanky-yaka-pobachyla-ves-svit-abo-dyvovyzhniobriji-sofiji-yablonskoji/; Vira Aheieva, "Sofiia Iablonska: Kruhosvitnia podorozh ukrainskoi reporterky" [Sofiia Iablonska: Round-the-world trip of Ukrainian reporter], BBC News Ukraine, 15 May 2017, https://www.bbc.com/ukrainian/blogs-39919135; Volodymyr Moroz, “Ii 
nalezhyt' tsilyi svit, daleki obrii Sofii Iablonskoi" [The whole world belongs to her, the distant horizons of Sophia Yablonska], Tyzhden, 9 May 2017, https://tyzhden.ua/History/191825; Yaroslav Stekh, "Sofiia Iablonska obiikhala ves' svit" [Sophia Yablonska traveled around the world], Svoboda, 10 March 2017, http://svoboda-news.com; see Tymofii Havryliv, "Char Maroka" [Charm of Morocco], Zbruč, 14 March 2016, https://zbruc.eu/node/48925; Tymofii Havryliv, "Z krainy ryzhu ta opiu" [From the country of rice and opium], Zbruč, 15 March 2017, https://zbruc.eu/node/63477; Tymofii Havryliv, "Daleki obrii" [Distant horizons], Zbruč, 22 March 2017, https://zbruc.eu/node/63795; Tymofii Havryliv, "Usmishka Buddy" [Buddha's smile], Zbruč, 16 March 2018, https://zbruc.eu/node/77737.

22. See the chapter "Hierarchies of Genres and Canons of Literature," in Kinds of Literature: An Introduction to the Theory of Genres and Modes, by Alastair Fowler (Oxford: Clarendon Press, 1982), 213-234.

23. Annette Deeken and Monika Bösel, "An den süßen Wassern Asiens": Frauen Reisen in den Orient ["On the sweet waters of Asia": Women travel to the Orient] (Frankfurt: Campus Verlag, 1996), 13.

24. See Homeniuk and Benytskyi, "Biografiia."

25. See David Fraley, Modernist Travel Writing: Intellectuals Abroad (Columbia: University of Missouri Press, 2010); Alexandra Peat, Travel and Modernist Literature: Sacred and Ethical Journeys (New York: Routledge, 2011).

26. Joyce Kelley, Excursions into Modernism: Women Writers, Travel, and the Body (New York: Routledge, 2016), 2, 4.

27. Kelley, Excursions into Modernism, 4.

28. See Yuri Lavrinenko, ed., Rozstriliane Vidrodzhennia: Antolohia 1917-1933; Poezia—prozadrama-esei [Executed Renaissance: Anthology 1917-1933; Poetry-prose-drama-essay] (Paris: Instytut Literacki, 1959).

29. See Bohdan Kravtsiv, ed., Obirvani struny: Antolohia poezii poliahlykh, zamuchenykh, rozstrilianykh i zaslanykh 1920-1945 [The broken strings: Anthology of poetry of the killed, tortured, shot, and deported 1920-1945] (New York: Naukove tovarystvo im. T. Shevchenka v Kanadi, 1955).

30. See Vira Aheieva, ed., Ukrainska mala proza XX stolittia [Ukrainian short fiction of the twentieth century] (Kyiv: Fakt, 2007).

31. Iaryna Tsymbal, Shliachy pid sontsem [Roads under the sun] (Kyiv: Tempora, 2016); Iaryna Tsymbal, "Krai zemli: Desiat' naiekzotychnishyr reportazhiv 1920kh rokiv" [The edge of the earth: Ten of the most exotic reports of the twenties], Litaccent, 1 August 2019, http:// litakcent.com/2019/08/01/kray-zemli-10-nayekzotichnishih-reportazhiv-20-h-rokiv/.

32. Homeniuk and Benytskyi, "Biografiia," 212-213.

33. Martha Bohachevsky-Chomiak, Feminists Despite Themselves: Women in Ukrainian Community Life, 1884-1939 (Edmonton: Canadian Institute of Ukrainain Studies, 1988), 152. 291.

34. Homeniuk and Benytskyi, "Biografiia," 219; Iablonska, Lysty z Paryzha, lysty z Kytaiu,

35. Iablonska, Lysty z Paryzha, lysty z Kytaiu, 292-293.

36. Prokhasko, "Teura."

37. Borkowska et al., Wspólnota wyobrażona, 6.

38. Svoboda Dimitrova-Moeck, Women Travel Abroad 1925-1932 (Berlin: Weidler Buchverlag, 2009), 9.

39. Ute Gacs, Aisha Khan, Jerrie McIntyre, and Ruth Weinberg, eds., Women Anthropologists: Selected Biographies (Chicago: University of Chicago Press, 1989), xiv.

40. Sidonie Smith, Moving Lives: Twentieth-Century Women's Travel Writing (Minneapolis: Minnesota University Press, 2001), x. 
41. Dúnlaith Bird, Travelling in Different Skins: Gender Identity in Women's Oriental Travelogues, 1850-1950 (Oxford: Oxford University Press, 2012), 2.

42. Iablonska, Char Maroka, Z krainy ryzhu ta opiu, Daleki obrii, 42.

43. According to Serhy Yekelchyk, "more than 26 million strong in 1900 (22.4 million in the Russian Empire and 3.8 million in Austrian-Hungary), Ukrainians were Europe's largest national minority and the second-largest Slavic people after the Russians. Their impressive numbers notwithstanding, both Eastern and Western Ukrainian fit the sociological criteria of so-called small people, or nondominant ethnic groups." After World War I, "western Ukraine, which is best defined in the interwar period as the Ukrainian-inhabited territories outside the Soviet Union, was now larger than it had been under the Habsburgs. More than 7 million strong by the early 1930s, western Ukrainians constituted one of the largest stateless minorities in interwar Europe." Serhy Yekelchyk, Ukraine: Birth of a Modern Nation (Oxford: Oxford University Press, 2007), 53.

44. Iablonska, Lysty z Paryzha, lysty z Kytaiu, 310.

45. Kalytovska, "Sofiia Iablonska," 59.

46. Iablonska, Char Maroka, Z krainy ryzhu ta opiu, Daleki obrii, 45.

47. Ibid., 102.

48. Ibid., 40.

49. Ibid., 38, 39 .

50. Ibid., 66 .

51. Ibid., $85,89$.

52. Ibid., 84 .

53. Ibid., 90.

54. Aleksandr Etkind, Tolkovanie puteshestvii: Rossiia i Amerika v travelogakh $i$ intertekstakh [Interpretation of travels: Russia and America in travelogues and intertexts] (Moscow: NLO, 2001), 4 .

55. Rita Felski, Beyond Feminist Aesthetics: Feminist Literature and Social Change (Cambridge, MA: Harvard University Press, 1989), 93.

56. Maria G. Rewakowicz, “Women's Literary Discourse and National Identity in PostSoviet Ukraine," in Contemporary Ukraine on the Cultural Map of Europe, ed. Larissa M. L. Zaleska Onyshkevych and Maria G. Rewakowicz (Armonk, NY: M. E. Sharpe, 2009), 285.

57. Rewakowicz, "Women's Literary Discourse and National Identity in Post-Soviet Ukraine," 285.

58. Iablonska, Lysty z Paryzha, lysty z Kytaiu, 310.

59. Barbara Korte, Der Englische Reisebericht: Von der Pilgerfahrt bis zur Postmoderne [The English travelogue: From the pilgrimage to postmodernism] (Darmstadt: Wiss. Buchges., 1998), 17.

60. See Rosi Braidotti, Nomadic Subjects: Embodiment and Sexual Difference in Contemporary Feminist Theory (New York: Columbia University Press, 1994); Iwona Boruszkowska, "Auto/ foto/bio/grafie Sofji Jabłonskiej: Praktykowanie nowoczesności" [Auto/photo/bio/graphy of Sofiia Iablonska: Practicing modernity], in Wspólnota wyobrażona: Pisarki Europy Środkowej wobec problemów literackich, społecznych i politycznych lat 1914-1945 [Imagined community: Women writers of Central Europe in the face of literary, social, and political problems of 1914-1945], ed. Grażyna Borkowska, Iwona Boruszkowska, and Katarzyna Nadana-Sokołowska (Warsaw: Instytut Badań Literackich PAN, 2017), 375-391; Boruszkowska, "Świadomy nomadyzm: Translokacje Sofii Jabłońskiej-opowieści (o) tożsamości w ruchu" [Conscious nomadism: Translocations of Sofiia Iablonska—stories (about) identity in movement], in Migracyjna pamięć, wspólnota, tożsamość [Migratory memory, community, and identity], ed. Roma Sendyka, Ryszard Nycz, and Tomasz Sapota (Warsaw: IBL, 2016), 174-186. 
61. Iablonska, Char Maroka, Z krainy ryzhu ta opiu, Daleki obrii, 85.

62. Ibid., 25.

63. Ibid., 29.

64. Ibid., 28.

65. Ibid.

66. Ibid., 35.

67. Ibid., 103.

68. The first version of the title of The Charm of Morocco was Me and Morocco; see Iablonska, Teura, 214.

69. Iablonska, Lysty z Paryzha, lysty z Kytaiu, 326.

70. Iablonska, Char Maroka, Z krainy ryzhu ta opiu, Daleki obrii, 29.

71. Ibid., 105.

72. Ibid., 42-43.

73. Ibid., 51.

74. Ibid., 55.

75. Ibid., 97.

76. Ibid., 95.

77. Ibid., 77.

78. Ibid.

79. Ibid., 146.

80. Ibid., 148.

81. Ibid., 150.

82. Ibid., 163.

83. Ibid., 164.

84. Ibid., 167, 168.

85. Ibid., 164.

86. Iablonska, Lysty z Paryzha, lysty z Kytaiu, 316.

87. Ibid., 311.

88. Ibid., 297; Iablonska, Char Maroka, Z krainy ryzhu ta opiu, Daleki obrii, 104.

89. Ibid., 91.

90. Iablonska, Lysty z Paryzha, Lysty z Kytaiu, 343. 